Article

\title{
Developing a Regression Model of Cooperative Learning Methodology in Pre-Service Teacher Education: A Sustainable Path for Transition to Teaching Profession
}

\author{
Francisco D. Guillén-Gámez $\mathbb{D}$, Lina Higueras-Rodríguez $\mathbb{D}^{\mathbb{D}}$ and Marta Medina-García * \\ Department of Didactics and School Organization, Faculty of Education, University of Almería, \\ 04120 Almería, Spain; dguillen@ual.es (F.D.G.-G.); mlinahr@ual.es (L.H.-R.) \\ * Correspondence: mmedina@ual.es
}

Received: 24 February 2020; Accepted: 8 March 2020; Published: 12 March 2020

check for updates

\begin{abstract}
There is a growing interest in the study of active methodologies, especially cooperative learning. It will allow for skills related to the positive interdependence between the components of a group, individual responsibility, the encouragement of interaction, and the development of social skills to be put into practice by pre-service teachers, as well as for the sharing and assertiveness of the ideas of teamwork. The purpose of this study is to predict those variables that significantly positively affect pre-service teachers' perceptions about the use of cooperative learning methodology in their initial training at university once it has been put into practice in the classroom for 3 months. For this, a quasi-experimental design was implemented to enable its practice, and subsequently the perceptions of the pre-service teachers were collected through the use of a questionnaire. The sample was composed of 140 pre-service teachers from the Faculty of Education of the University of Almeria (Spain). The overall results of the study determined that the interest of pre-service teachers in their subject, age, attendance of practical classes, and the type of education level they have had access to positively affect the perceptions of pre-service teachers, while positive academic performance causes a decline. These findings highlight the need to continue research, mainly on the question of why working in cooperative groups causes a decrease in academic performance.
\end{abstract}

Keywords: cooperative learning; pre-service teachers; university education; regression

\section{Introduction}

Teacher trainers must provide pre-service teachers with enough skills and strategies to teach their future students how to create and live together in a sustainable world [1,2].

To promote sustainable education, pre-service teachers must understand the relationship between their teaching practice and society and the environment. Therefore, through the curricula of educational degrees, sustainability competencies must be transferred to pre-service teachers to enable their personal and professional development $[3,4]$. These competencies are related to critical thinking, strategic action, and relationships between people $[5,6]$, as well as the promotion of positive values, taking into account cognitive, procedural, and attitudinal differences [7]: Cognitive differences relate to the knowledge and contents of the subject area and the stage on which the learning takes place; procedural differences include diverse tools, strategies, and tasks, allowing the process of an educational practice; attitudinal differences are related to personal growth and the promotion of positive values [8]. From this ideal, progress that allows living with any type of society and culture will be achieved, by being empathetic, supportive, non-racist, and fair with others [9]. In summary, the aim is to work on the values and skill developments that are promoted by this inclusive schooling method by relying on 
there being a richness of diversity present in all people and, in this way, to also act in accordance with one of the guiding principles supported by the World Education Agenda 2030, within the framework of Sustainable Development Goal 4 (ODS 4), which has been adopted by the international community. ODS 4 is human rights-based and aims to ensure that people have full enjoyment of the right to education as a catalyst for sustainable development, of which the purpose is to promote lifelong learning opportunities and ultimately to ensure inclusive, equitable, and quality education [10].

In this context, authors, such as Cañabate et al. [11] or Velázquez et al. [12], affirm that pedagogical interest has been based in showing how cooperative learning represents a key role in the development of transversal competencies, as well as civic citizen skills that will enable sustainable development to be achieved in the face of complex problems in the near future [13-15], thus promoting new didactic pedagogical models that encourage the learning of pre-service teachers on a significant level $[8,16]$. To this end, the teacher must implement strategies and methodologies that promote teamwork, so that pre-service teachers learn to manage, build, and organize their learning in an autonomous and cooperative way [17].

Within this field of research, three types of educational situations have been identified, with the following social dimensions taken into account: individualistic, competitive, and cooperative [13]. Different studies indicate, in this sense, that the cooperative learning environment is more favorable, both for student achievement, as it improves their academic performance, and for the promotion of their civic social skills $[18,19]$. On the other hand, Pujolás [20] and Muñiz et al. [21] state that learning based on the cooperative structure can be a useful tool for all ages and contexts and for students with both low and high performance. Research based on cognitive styles has shown that there are different ways of learning and approaching knowledge, which profoundly affect the performance of individuals and their approach to education for sustainable development [22].

However, having students learn collaboratively can create difficulties between group members in managing the relationships between them [23], such as social laziness [24] and disruptive conflict [25]. Therefore, the teacher's job is to provide pedagogical support to students [26], offering them the necessary resources and promoting a pleasant working environment, in which the spontaneity of the students and their interest in learning can take place [27], as well as providing continuous and personalized follow-up for both the working group and each student individually [28,29].

Given that collaborative learning in the education field has great importance for sustainable development, the present work aims to find out if different academic and personal variables significantly influence the perceptions of pre-service teachers about the use of learning the teaching methods of cooperative learning once this methodology has been applied in the classroom for 3 months. Therefore, the research question is: What variables significantly affect the perceptions of pre-service teachers about a cooperative learning methodology?

\section{Theoretical Framework}

\subsection{Approach to the Concept of Cooperative Learning}

Cooperative learning is defined as an educational methodology based on work in small and, generally, heterogeneous groups, in which students work together to improve their own learning and that of other members of their group [21,30,31]. According to Carrasco et al. [32], in the conceptual approach, cooperative learning implies the presence, during group work, of five essential characteristics: (1) resources and roles, which include, among others, (2) face-to-face interaction; (3) individual responsibility, which implies that no one can adopt a passive attitude but is responsible for his/her work; (4) interpersonal and small-group work skills; and (5) group processing or the process through which the group identifies the behaviors that manifested during the development of the task, determining which behaviors contributed to the achievement of the task and which ones were harmful, in order to reinforce the first behaviors and propose alternatives to the second. 
Alternatively, authors as Casey and Goodyear [33] and Johnson and Johnson [34] have identified five main characteristics related to cooperative learning: social/interpersonal skills (active listening, feedback of comments or praise for the efforts of others), group processing (discussing and reflecting on group work), positive interdependence (which refers to all group members depending on each other to achieve the expected purpose), supportive interaction (face-to-face interaction of group members during tasks), and individual responsibility (each group member is responsible for a part of the group task). In short, cooperative learning is nowadays considered an important teaching-learning strategy which can promote academic, social, and affective-motivational achievements for students, bearing in mind those with specific educational needs [20,35]. It also improves individual responsibility for group success [36], as well as motivation to continue working and learning with the help of their group [37].

\subsection{Related Works}

Cooperative learning has been identified as one of the most promising methodologies, considering all types of teaching methods associated with fostering student growth. Consequently, in the last few years, extensive scientific reviews have been focused on pre-service teachers in relation to their improved academic performance [11,38-40]; their motivation [41,42]; and their perceptions in group work [43-45].

Despite the importance of these studies, which analyse the influence of collaborative learning on pre-service teachers, the literature has been limited in two aspects: both in studies focused on pre-service teachers and studies focused on identifying the significant variables that can help to improve the perceptions of pre-service teachers regarding the implementation of this type of methodology in classroom, which uses regression methods.

Ahn and Nelson [46] investigated the effectiveness of cooperative learning with a sample of 850 engineering students from a Midwestern university (unspecified). Although the students determined that they enjoyed working in teams, different regressions found that variables, such as gender, class attendance, or grade average score, had no impact on their perceptions. However, authors, such as Hossain [47], Molla and Muche [48], and Yamarik [49], showed that this methodology use did point out a positive effect on academic performance. For example, Vallet-Bellmun et al. [50], with a sample of 319 students from different university degrees of Business Administration, Finance and Accounting, and Economics, clarified that cooperative learning improves the acquisition of the given subject in which it is applied, along with the team performance.

In the same context, Weinberger and Shonfeld [51] investigated which variables influence 305 future education teachers at The Hebrew University (Jerusalem), with respect to the use of collaborative learning in their own teaching. Using a hierarchical regression model, the results determined that grade, gender, and age did not influence the prediction of the use of cooperative learning, while their attitude and interest in working in groups did. Along similar lines, Deerfield [31] investigated the effects of cooperative learning and its relationship to test scores with a sample of 144 students from a public university in the Mid-Atlantic region of the United States, as regards the Macroeconomics subject. Through several linear multiple regressions, the authors found that gender, ethnicity, and age did not show any significant effect, while class attendance, subject interest, and grades did predict an improvement in cooperative learning. Similar results regarding student interest and satisfaction in this type of learning were found by Morales [52] and Hyun et al. [53], as well as regarding gender and age by Uzunboylu and Kinik [54]. Nevertheless, Zhang et al. [55] drew a sample of 515 higher education students, in which they pointed out that gender, educational level, and performance concern the learning of English through this methodology.

If we bear in mind the different investigations dealing with cooperative learning in Higher Education, as we have justified before, we can draw the following conclusions: There are few studies analyzing pre-service teachers in which academic and personal variables can influence perception regarding the implementation of cooperative learning as an active methodology in the classroom, making use of regression methods; additionally, there has not been enough research into the effects 
of the age of the pre-service teachers, if he/she has a scholarship, if he/she has repeated the subject before, and the frequency of class attendance, among other variables. Therefore, through this work, the field of study is extended by including these variables, which makes the present research more solidly based. This is the main contribution and objective the authors make to the scientific field: The prediction of variables that significantly affect student perception regarding the use of cooperative learning methodology in classroom.

\section{Method}

\subsection{Design}

First, a quasi-experimental design was carried out, in which the cooperative learning methodology was implemented for 3 months. Once the subject was finished, the survey method was used to collect the perceptions of participants. Once data was collected and subsequently processed, descriptive and inferential analyses were carried out in order to measure the pre-service teachers' perceptions under the cooperative learning methodology, as well as to predict the significant variables involving these perceptions.

\subsection{Participants}

For the sample collection, a non-probabilistic sample was used intentionally for the purpose of measuring the perceptions of the pre-service teachers to which the cooperative learning methodology was employed and worked on in the classroom. The sample composed of 144 pre-service teachers from the Early Education and Primary Education Degrees of the University of Almeria.

\subsection{Cooperative Learning Procedure}

To carry out the cooperative learning methodology along the different subjects, working groups of 3-6 people were set up. To this end, the goal was established on the "Master-Apprentice" dynamic, where one member of each group assumed the role of teacher while the rest acted as apprentices. The point was that each one of them would assume their role and would work in a collaborative manner, while taking responsibility for the entire learning process. Within the working groups, an incentive system was introduced to provide effectiveness to the process, as they were entitled to a series of group bonuses that had an impact on the final grade. The roles of each group member switched every 2 weeks. The aim of this election was so that each member could experience the different roles of teacher/apprentice, thus achieving a distributed and inclusive leadership, since all students had the same opportunities.

The sample belonged to the subjects: "Educational Innovation in Primary Education", "Didactics and Organization in Primary Education I", and "Tutorial Action and Child Care in Infant Education". The first subject focused on learning different innovative methodologies in order to implement them with the pre-service teachers. We worked on the following curricular contents: educational innovation, pedagogical alternatives, and the role of teachers regarding this type of methodology. The second subject was centered around learning the educational principles that must support a social and fair education. We worked on the following contents: the curriculum for the construction of democratic schools, the functions of the school, and different resources for the quality of the school organization. One of the purposes of the third subject was learning the main aspects of the tutorial action as an essential part of its functions, focusing on the integral development of pre-service teachers. In the same way, the contents focused on aspects such as attention to diversity in the concept of childhood.

\subsection{Instrument Description}

To measure the perceptions of pre-service teachers on the implementation of the cooperative learning methodology, the Cooperative Learning Questionnaire, developed by Fernandez-Rio et al. [56], was used. The instrument involved 20 items classified in five dimensions through a 5-point Likert scale 
(totally disagree, value 1; disagree, value 2; neutral, value 3; agree, value 4; and totally agree, value 5). The first dimension was entitled "social skills" and focused on the components of each group to develop interpersonal communication skills for management, as well as for leadership (e.g., listening to the opinions and points of view of our peers). The second dimension was called "Group Processing" and focused on the sharing of ideas and reflections (e.g., making decisions in a consensual manner among group peers). The third dimension, "Positive Interdependence", was about the dependence that group members have on each other to achieve the objectives of the tasks (e.g., it is important to have the help of my colleagues to complete the tasks). The fourth dimension, "Encouraging Interaction", referred to the communication and direct interaction between group members (e.g., peers relating and interacting during tasks). The last dimension, "Individual Responsibility", referred to the responsibility of each member in the completion of tasks (e.g., each group member should try to participate, even if he or she does not like the task). Within the second dimension, an item related to leadership was incorporated, as we considered that cooperative learning promotes distributed leadership (e.g., we consider it important for someone to coordinate the group). This item was introduced as stated by Sun et al. [57]: Cooperative learning can promote effective leadership, which helps solving problems among pre-service teachers. The questionnaire was composed of two parts. The first part included the variables, Gender, Age, Scholarship, Access, Mark, Repeater, Class Attendance, Interest subject, presented in Table 1 (which are included in the category "Academic and personal" in Table 2).

Table 1. Definition of variables (dependent variables (DV)).

\begin{tabular}{ll}
\hline Short Name & Description \\
\hline $\mathrm{Y}_{0}$ & Total pre-service teacher perception of cooperative learning (DV) \\
$\mathrm{Y}_{1}$ & Pre-service teacher perception of their social skills (DV) \\
$\mathrm{Y}_{2}$ & Pre-service teacher perception of Group Processing (DV) \\
$\mathrm{Y}_{3}$ & Pre-service teacher perception of Positive Interdependence (DV) \\
$\mathrm{Y}_{4}$ & Pre-service teacher perception of Encouraging Interaction (DV) \\
$\mathrm{Y}_{5}$ & Pre-service teacher perception of Individual Responsibility (DV) \\
Gender & Gender of the pre-service teacher team. (Female, value 1; Male, value 0) (Nominal) \\
Age & Pre-service teacher age (Scale) \\
Scholarship & Have you had a scholarship this year? (Yes, value 1; No, value 0) (Nominal) \\
Access & How did you get into the degree? (Formative cycle, value 0; Baccalaureate, value 1). Nominal \\
Mark & Mark in the subjects (Scale) \\
Repeater & Are you repeating the course? (Yes, value 1; No, value 0) (Nominal) \\
Class Attendance & From 1 to 10, how often do you attend practice classes? (Scale) \\
Interest Subject & From 1 to 10, what is your interest in learning the subject? (Scale) \\
\hline
\end{tabular}

Source: Own elaboration.

The original instrument was applied to a sample of primary and secondary school pre-service teachers, providing a good adjustment for reliability and construct validity through confirmatory factor analysis (CFA). However, a sample of pre-service teachers was employed for the present research, so the psychometric properties were still adequate. The sample was split in two parts to check both types of validity.

Table 1 shows the list of research variables: the dependent variables (DV) and the category of independent variables (the rest of the variables).

\subsection{Procedure and Data Analysis}

Data analysis was performed using IBM SPSS Statistics 22.0 statistical software (Armonk, NY, USA). To carry out the correct analysis of the data, different techniques were taken into account:

(a) The average obtained in the perceptions of the pre-service teachers on the cooperative learning methodology.

(b) In order to predict those variables specified in Table 1, different linear multiple regression models were carried out. For this purpose, the ordinary least-squares method was used, following a stepwise approach. Nominal variables were reconverted into dummy variables to be able to 
introduce them into this type of technique, using for them the 0 and 1 value. In addition, the assumptions that allow this type of inferential technique were controlled for non-infringement.

\section{Results}

The results section is divided into three sections. The first section is dedicated to the analysis of the psychometric properties of the instrument; the second section focuses on descriptively understanding the pre-service teacher perceptions once the cooperative learning methodology was applied in the classroom; and the third section, in turn, centers on understanding which variables significantly predict the perceptions, regarding cooperative learning.

\subsection{Instrument Psychometric Analysis}

Reliability was measured through Cronbach's alpha, which showed very satisfactory levels in the total instrument, as well as in each of its dimensions (total, $\alpha=0.96$; Social skills, $\alpha=0.81$; Group processing, $\alpha=0.84$; Positive Interdependence, $\alpha=0.92$; Encourage interaction, $\alpha=0.94$; and Individual responsibility, $\alpha=0.96$ ).

The dimensionality of the data through exploratory factor analysis (EFA) showed the fit of the model through the Kaiser-Meyer sample fit $(\mathrm{KMO}=0.908)$, as well as the sphericity of Barlett $(\mathrm{X} 2$ $=1721.348 ; p<0.05)$. Using the maximum likelihood method by oblique rotations Oblimin, the five dimensions were explained through evidences at $85.22 \%$, regarding the total true variance of the instrument. However, two items did not correctly saturate their dimension, so they were eliminated from the questionnaire. Appendix A contains the questionnaire with the final items. On the other hand, in Figure 1 observs the confirmatory factor analysis (CFA). This model correctly fits the theoretical model proposed by Fernandez-Rio et al. [56], which meets the correct coefficients in the allowed thresholds, according to Bentler [58] and Hu and Bentler [59]: CMIN/DF (chi square mean/degree of freedom $)=1.91, p=<0.001$; CFI (comparative fit index $)=0.934$; TLI (Tucker-Lewis index) $=0.919$; IFI $($ incremental fit index $)=0.935$; RMSEA (root mean square error of approximation $)=0.77$. This model evidences the factorial structure formulated in the CFA, composed by five correlated latent variables. The structural equation model was made in AMOS V.22 software (Illinois, Chicago, USA).

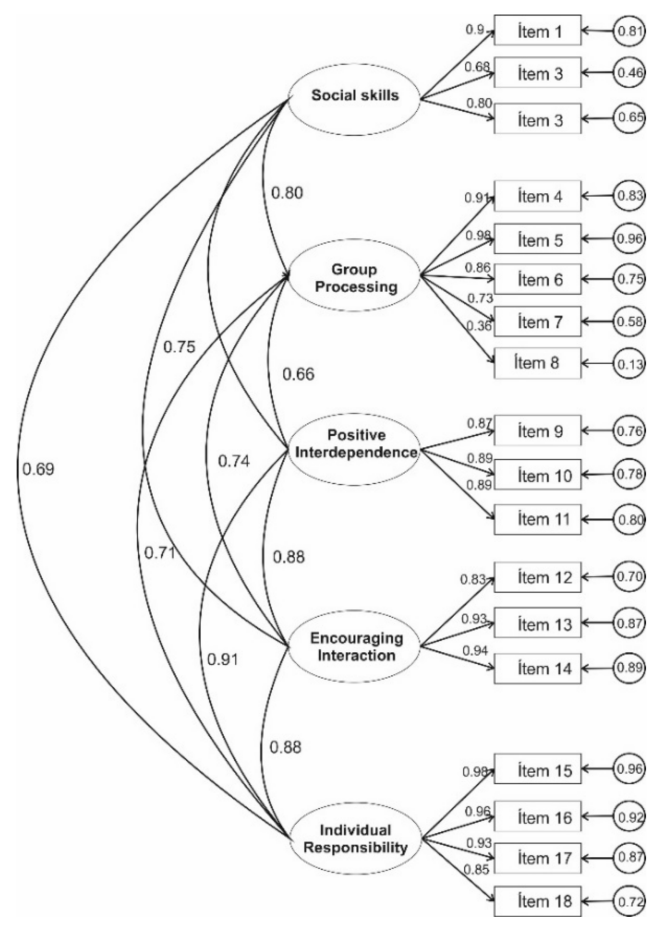

Figure 1. Structural equation model. 


\subsection{Descriptive and Inferential Results on Pre-Service Teacher Perceptions}

Table 2 shows the descriptive results for 140 pre-service teachers. The scale variables specified in Table 1 were categorized into nominal variables for the purpose of providing concrete descriptive data about perceptions. In Table 2, the overall perception of the participants is shown, taking into account all the dimensions of the instrument. This global perception is shown through the mean, standard deviation, and mean.

Table 2. Basic descriptive data and average pre-service teacher perceptions.

\begin{tabular}{|c|c|c|c|c|c|}
\hline \multicolumn{3}{|c|}{ Variables Academic and Personal } & \multirow{2}{*}{$\begin{array}{c}\text { Global Perception Average } \\
4.28\end{array}$} & \multirow{2}{*}{$\frac{\text { Standard Deviation }}{0.65}$} & \multirow{2}{*}{$\begin{array}{c}\text { Mean } \\
4.51\end{array}$} \\
\hline \multirow{5}{*}{ Personal } & \multirow{2}{*}{ Gender } & Male & & & \\
\hline & & Female & 4.34 & 0.68 & 4.60 \\
\hline & \multirow{3}{*}{ Age } & $18-20$ & 4.36 & 0.67 & 4.59 \\
\hline & & $21-22$ & 4.31 & 0.71 & 4.63 \\
\hline & & $23-+$ & 4.21 & 0.67 & 4.43 \\
\hline \multirow{15}{*}{ Academic } & \multirow{2}{*}{ Scholarship } & Yes & 4.36 & 0.64 & 4.53 \\
\hline & & Not & 4.29 & 0.71 & 4.58 \\
\hline & \multirow{2}{*}{ Access } & Formative cycle & 4.49 & 0.51 & 4.64 \\
\hline & & Baccalaureate & 4.25 & 0.72 & 4.53 \\
\hline & \multirow{3}{*}{ Mark } & $0-5$ & 4.46 & 0.50 & 4.53 \\
\hline & & $5,1-7$ & 3.97 & 0.73 & 4.14 \\
\hline & & $7,1-10$ & 4.38 & 0.69 & 4.69 \\
\hline & \multirow{2}{*}{ Repeater } & Not & 4.32 & 0.69 & 4.59 \\
\hline & & Yes & 4.46 & 0.30 & 4.51 \\
\hline & \multirow{3}{*}{$\begin{array}{l}\text { Class } \\
\text { attendance }\end{array}$} & $0-5$ & 3.57 & 0.63 & 3.43 \\
\hline & & $6-7$ & 4.36 & 0.66 & 4.60 \\
\hline & & $8-10$ & 4.50 & 0.71 & 4.50 \\
\hline & \multirow{3}{*}{ Interest subject } & $0-5$ & 3.36 & 0.96 & 3.09 \\
\hline & & $6-7$ & 4.32 & 0.56 & 4.44 \\
\hline & & $8-10$ & 4.37 & 0.66 & 4.62 \\
\hline
\end{tabular}

The distribution around gender showed that females $(M=4.34)$ had slightly higher perceptions than males $(M=4.28)$. In terms of age, the results revealed that the sample comprising an age range between 18 and 20 years old showed a higher perception $(M=4.36)$ in contrast to pre-service teachers between 21 and 22 years old $(\mathrm{M}=4.31)$ and those who were over 23 years old $(\mathrm{M}=4.21)$. It was determined that pre-service teachers who had received some type of scholarship or aid to study $(M=4.36)$ had slightly higher levels than those who had not received any aid $(M=4.29)$.

In terms of access, pre-service teachers who had gone to university through the baccalaureate showed a lower level $(M=4.25)$ in contrast to those who had gone through vocational training $(M=4.49)$. In the pre-service teacher grade obtained at the end of the course, perceptions of cooperative learning were classified in three categories: pre-service teachers with a score below 5 points $(\mathrm{M}=4.46)$; pre-service teachers with a score between 5.1 and 7 points $(M=3.97)$; and pre-service teachers who obtained a score above 7.1 points $(M=4.38)$. Those who had repeat a grade $(M=4.46)$ had a slightly higher level in their perceptions of cooperative learning methodology in comparison to those who had not repeated a grade $(\mathrm{M}=4.32)$.

In terms of class attendance, it was observed that those pre-service teachers who attend classes with a frequency lower than or equal to 5 days showed a lower level $(\mathrm{M}=3.57)$ compared to those who attend classes between 6-7 days $(\mathrm{M}=4.36)$ or those who always attend classes $(\mathrm{M}=4.50)$. Regarding the subject interest, those pre-service teachers who valued their interest with less than 5 points on the Likert scale had less favorable perceptions $(M=3.36)$ over those who were very interested $(M=4.37)$.

\subsection{Prediction of Significant Variables in Pre-Service Teacher Perceptions}

The assumptions of independence from residuals were verified through the Durbin-Watson statistic (D.W. $=2.009)$ and multicollinearity through tolerance coefficients with values greater than 0.8 , as well as variance inflation factor (VIF), with values below 10 points $[60,61]$. 
The multiple linear regression model was employed since scale variables were used, as well as nominal variables, which were reconverted into dummy variables. Through the introduced regression procedure, we found the best model to predict pre-service teacher perceptions about cooperative learning. On every one of the regression models, all the descriptive variables in Table 1 were used.

Firstly, we used the $\mathrm{Y}_{0}$ model, in which the global instrument (set of all dimensions) is considered. The model, besides being significant, $\mathrm{F}(8,131)=3.813$; sig. $=0.01$, was able to predict $15 \%$ of the true variance of the cases $\left(R=0.44 ; R^{2}=0.19\right)$, so the model was acceptable.

Secondly, each regression model in each dimension of the instrument was analyzed. The $Y_{1}$ model (pre-service teacher understanding of their social skills) was significant, $\mathrm{F}(8,131)=2.323$; sig. $=0.023$, which explained $13 \%$ of the subjects' true scores $\left(R=0.35 ; R^{2}=0.13\right)$. The $Y_{2}$ model (pre-service teacher perceptions of Group Processing) was significant, $F(8,131)=2.225$; sig. $=0.029$, explaining $12 \%$ of the subjects' true scores $\left(R=0.035 ; R^{2}=0.12\right)$. The $Y_{3}$ model (pre-service teacher perceptions of Positive Interdependence) was significant, $F(8,131)=4.359$; sig. $=0.001$, explaining $21 \%$ of the true scores $\left(\mathrm{R}=0.46 ; \mathrm{R}^{2}=0.21\right)$. The $\mathrm{Y}_{4}$ model (pre-service teacher perceptions of Individual Responsibility) was significant, $\mathrm{F}(8,131)=4.648$; sig. $=0.001$, explaining $22 \%$ of the true variance of the subjects' scores $\left(\mathrm{R}=0.47 ; \mathrm{R}^{2}=0.22\right)$. Finally, the $\mathrm{Y}_{5}$ model (pre-service teacher perceptions of Encouraging interaction) was significant, $F(8,131)=3.095$; sig. $=0.003$, explaining $16 \%$ of the scores $\left(R=0.40 ; R^{2}=0.16\right)$.

The different equation lines with those variables that were significant predictors in each model along with their corresponding constants are stated as follows:

$\mathrm{Y}_{0}=3.548+0.298$ Interest_Subject -0.187 Access -0.212 Age +0.170 Class Attendance

$\mathrm{Y}_{1}=5.189-0.264$ Acces -0.297 Age

$\mathrm{Y}_{2}=4.559+0.202$ Interest_Subject -0.241 Age

$\mathrm{Y}_{3}=2.083+0.246$ Interest_Subject -0.202 Mark +0.280 Class Attendance

$\mathrm{Y}_{4}=2.315-0.168$ Age +0.343 Interest_Subject +0.229 Class Attendance

$\mathrm{Y}_{5}=3.596+0.299$ Interest_Subject -0.194 Age

\section{Discussion}

The aim of this study is to predict those variables affecting the perceptions of pre-service teachers about the use of active methodologies, specifically cooperative learning.

The results indicated that, on the one hand, that there were a number of differences in the perception that pre-service teachers of early childhood and primary education have in terms of cooperative learning. Thus, variables such as gender (women), age (being between 18 and 20 years old), studies (to obtain a scholarship for study purposes), and vocation (going to university through vocational training) present slightly lower perceptions on cooperative learning compared to pre-service teachers who had repeated the subject. This data differs subtly from research findings, such as Muñíz et al. [21] and Pujolás [20], which indicate that learning based on cooperative structure can be a useful tool in all ages, contexts, and pre-service teachers of both low and high performance.

On the other hand, through the achievement of six regression models, we collected the variables that significantly predict pre-service teacher perceptions over cooperative learning, among which the following stand out: The interest that teachers show for the subject, the age, class attendance of practical classes, and access to university.

If we compare our results with other investigations, we find similarities in relation to class attendance and the results of Deerfield's work [31], from which it is derived that this variable does predict an improvement in cooperative learning. However, in opposition to them, we found the study by Ahn and Nelson [46], which shows that class attendance does not influence perceptions of cooperative learning.

Likewise, according to the age variable, despite our significant results in this regard, several investigations such as those by Hyun et al. [53], Weinberger and Shonfeld [51], Uzunboylu and Kinik [54], Morales [52], and Deerfield [31] draw opposite conclusions stating that age does not 
influence the prediction of the use of cooperative learning. We consider that this may be due to a greater demand from older pre-service teachers, who are the most critical when it comes to assessing collaborative learning. These pre-service teachers probably make a greater effort to become teachers, which results in a greater expectation of the course content and not so much for the acquisition of other types of skills resulting from the implementation of other more innovative methodologies.

Despite this, improvements in academic performance are often referred to as one of the greatest advantages or benefits of implementing cooperative learning $[18,19]$. As a result, there are multiple scientific reviews aimed at pre-service teachers in relation to their improved academic performance [11,38-40]. It is certain that data extracted from our study showed the opposite line: A decrease in perceptions, thus affecting this variable negatively. This conclusion is contrary to what has been stated in research, such as that of Yamarik [49], Hossain [47], Molla and Muche [48] or Vallet-Bellmun et al. [50], and Zhang et al. [55], who did find positive effects on academic performance and improved learning. We infer that the antagonism present in these results may be partly due to difficulties present, at times, in the very nature or dynamics that are established in collaborative learning, as is the case of difficulties in managing relationships [23], social laziness [24], and disruptive conflicts [25]. Another factor may be the profile of the pre-service teachers, to which we refer, that is, if data showed that good academic results negatively affect the perception of cooperative learning, which may be because both type of pre-service teachers are habituated to traditional, individualistic, and direct instruction-based learning.

\section{Limitation and Recommendation}

Some of the limitations found in the development of this study are the deficiencies found in the scientific literature, regarding research focused on pre-service teachers and expressly oriented to the object of our work. Therefore, it would be advisable to continue research on this subject in this educational context and, consequently, improve the power of generalization of the obtained results, since, given that it is not a probabilistic sample, the results must be extrapolated to similar contexts of pre-service teachers.

The results of our research have two clear practical implications: On the one hand, for the implementation of cooperative learning in general terms at all educational levels and for all its recipients, thus contributing to sustainable social development and, on the other hand, for the involvement of teacher liability to make substantial improvements and thus increase personal, motivational, and attitudinal skills adequate to achieve optimal and adequate development of this methodology.

\section{Conclusions and Future Works}

After the development of this work, we can extract several key ideas about the topic at hand. First, it is important to highlight the need for the entire education system, including university, to implement all kinds of strategies to promote sustainable development. It must be part of the educational approaches and programs and not only part of the improvement and innovation plans to which those professors committed to the subject are accepted. Therefore, these practices and approaches should be internalized in every teacher and applied in their daily activities.

The benefits of active methodologies and, specifically, cooperative learning in the development of all types of skills in pre-service teachers are demonstrated. Likewise, it is essential to expressly influence the training of future teachers to settle and develop these approaches. Proof of this is the present work, with which we contribute to an education for sustainable development, since part of the actual practice and since after analyzing the results, we provide relevant data on how to carry it out properly. By addressing education from the approaches to sustainable development, we are contributing to the achievement of the four main pillars of education established by United Nations Educational, Scientific and Cultural Organization (UNESCO), such as learning: knowing, doing, living, and being. We also have a direct impact on the formation of individuals able to face humanity's challenges to achieve fairer, more solidarity-based, and equitable societies. 
In short, mutual support and cooperation are sole characteristics of the human being, which are essential to guarantee sustainable social development. Fortunately, from the educational field, we have a methodology such as cooperative learning, and it is essential to enhance this characteristic because it is so necessary for the society of this century.

\section{Future Research}

Regarding future works, we propose the conducting of a study from a longitudinal perspective to know the evolution of the opinion of the respondents. It would also be important to make comparative studies between different educational systems, cultures, or countries. An important aspect is the inclusion of new variables, such as the study environment or personality characteristics of future teachers. In short, we should continue to focus on the investigation of pre-service teachers in kindergarten and primary education and active methodologies.

Author Contributions: Conceptualization, F.D.G.-G. and L.H.-R.; methodology, F.D.G.-G.; F.D.G.-G.; validation, F.D.G.-G.; formal analysis, F.D.G.-G.; investigation, L.H.-R. and M.M.-G.; resources, L.H.-R.; data curation, F.D.G.-G.; writing - original draft preparation, F.D.G.-G., L.H.R., and M.M.-G.; writing—review and editing, F.D.G.-G., L.H.-R., and M.M.-G.; visualization, L.H.-R.; supervision, F.D.G.-G.; project administration, F.D.G.-G., L.H.-R., and M.M.-G. All authors have read and agreed to the published version of the manuscript.

Funding: This research received no external funding.

Conflicts of Interest: The authors declare no conflicts of interest.

\section{Appendix A}

Table A1. Questionnaire to measure the perceptions of the pre-service teachers on cooperative learning in educational contexts. Prepared by Fernandez-Rio et al. [56].

\begin{tabular}{|c|c|c|c|c|c|}
\hline \multicolumn{6}{|c|}{$\begin{array}{l}\text { For each of the following items related to cooperative learning, indicate your degree of disagreement or agreement. It is a Likert scale } \\
\text { of } 5 \text { points, where the value } 5 \text { is the degree of total agreement. }\end{array}$} \\
\hline Social skills & 1 & 2 & 3 & 4 & 5 \\
\hline We work the dialogue, the ability to listen, and/or debate & & & & & \\
\hline We expose and defend ideas, knowledge, and points of view to colleagues & & & & & \\
\hline We listen to the opinions and points of view of colleagues & & & & & \\
\hline Group processing & 1 & 2 & 3 & 4 & 5 \\
\hline We expose our thoughts of something concrete in order to extract the best ideas & & & & & \\
\hline We make decisions by consensus among groupmates & & & & & \\
\hline We discuss ideas among group members & & & & & \\
\hline 7. We reflect individually and jointly within the group & & & & & \\
\hline We consider it important for someone to coordinate the group & & & & & \\
\hline $\begin{array}{l}\text { Positive Interdependence } \\
\end{array}$ & 1 & 2 & 3 & 4 & 5 \\
\hline The help of my colleagues is important to complete the tasks & & & & & \\
\hline We cannot finish an activity without the contributions of my group members & & & & & \\
\hline 11. If each member of the group does their tasks better, the group gets the best result & & & & & \\
\hline Encouraging Interaction & 1 & 2 & 3 & 4 & 5 \\
\hline Groupmates interact during tasks & & & & & \\
\hline 13. We interact with each other to do the activities & & & & & \\
\hline We work directly with each other & & & & & \\
\hline Individual responsibility & 1 & 2 & 3 & 4 & 5 \\
\hline Each member of the group must participate in the tasks of the group & & & & & \\
\hline Each group member must strive to carry out the activities of the group. & & & & & \\
\hline 17. Each member of the group should try to participate, even if they don't like the task & & & & & \\
\hline Each group member must do their part of the group's work to complete the task. & & & & & \\
\hline
\end{tabular}




\section{References}

1. Fuertes-Camacho, M.T.; Graell-Martín, M.; Fuentes-Loss, M.; Balaguer-Fàbregas, M.C. Integrating sustainability into higher education curricula through the project method a global learning strategy. Sustainability 2019, 11, 767. [CrossRef]

2. Tejedor, G.; Segalàs, J.; Barrón, Á.; Fernández-Morilla, M.; Fuertes, M.T.; Ruiz-Morales, J.; Hernández, À. Didactic strategies to promote competencies in sustainability. Sustainability 2019, 11, 2086. [CrossRef]

3. Chai, C.S.; Koh, J.H.L.; Tsai, C.-C. A review of technological pedagogical content knowledge. Educ. Technol. Soc. 2013, 16, 31-51.

4. Carrión-Martínez, J.J.; Fernández-Martínez, M.D.M.; Pérez-Fuentes, M.D.C.; Gázquez-Linares, J.J. Specific competencies in social work higher education in the framework of the European higher education area: The perception of future professionals in the Spanish context. Eur. J. Soc. Work 2020, 23, 43-55. [CrossRef]

5. González Fernández, N.; García Ruiz, R.; Ramírez García, A. Aprendizaje cooperativo y tutoría entre iguales en entornos virtuales universitarios. Estudios Pedagógicos (Valdivia) 2015, 41, 111-124. [CrossRef]

6. Mogren, A.; Gericke, N.; Scherp, H.Å. Whole school approaches to education for sustainable development: A model that links to school improvement. Environ. Educ. Res. 2019, 25, 508-531. [CrossRef]

7. Mendívil, L. Razones para jugar: Hacia la comprensión del rol del juego en el proceso de formación de docentes de educación inicial. Rev. De Educ. 2009, 8, 7-21. Available online: http://revistas.pucp.edu.pe/ index.php/educacion/article/view/1762 (accessed on 30 January 2020).

8. Higueras-Rodríguez, L. El juego como recurso didáctico en la formación inicial docente. Ph.D. Thesis, University of de Granada, Granada, Spain, 2019.

9. Darling-Hammond, L. Teaching for social justice: Resources relationships, and anti-racist practice. Multicult. Perspect. 2017, 19, 133-138. [CrossRef]

10. ONU (2015): Resolución de la Asamblea General de las Naciones Unidas. 17 Goals to Transform Our World: The Sustainable Development Goals in 2030. Available online: https://www.un.org/sustainabledevelopment/ education/ (accessed on 29 January 2020).

11. Cañabate Ortiz, D.; Serra Putellas, T.; Bubnys, R.; Colomer, J. Pre-Service Teachers' Reflections on Cooperative Learning: Instructional Approaches and Identity Construction. Sustainability 2019, 21, 5970. [CrossRef]

12. Velázquez, C.; Fraile, A.; López, V.M. Aprendizaje cooperativo en educación física. Movimento 2014, 20, 239-259. [CrossRef]

13. López, G.; Acuña, S. Aprendizaje cooperativo en el aula. Inventio la Génesis de la Cultura Universitaria en Morelos 2018, 7, 29-38.

14. Montalvo, M.J.G.; Martín, C.T. Group techniques as a methodological strategy in acquiring teamwork abilities by college students. J. Educ. Teach. Train. 2013, 4, 14-23.

15. Tondeur, J.; Aesaert, K.; Prestridge, S.; Consuegra, E. A multilevel analysis of what matters in the training of pre-service teacher's ICT competencies. Comput. Educ. 2018, 122, 32-42. [CrossRef]

16. Gudmundsdottir, G.B.; Hatlevik, O.E. Newly qualified teachers' professional digital competence: Implications for teacher education. Eur. J. Teach. Educ. 2018, 41, 214-231. [CrossRef]

17. Johnson, D.W.; Johnson, R.T. Cooperative learning and social interdependence theory. In Theory and Research on Small Groups; Springer: Boston, MA, USA, 2002; pp. 9-35.

18. Dorati, Y.; De Crespo, M.; Cantú, F. El aprendizaje cooperativo aplicado a las matemáticas y sus efectos en el rendimiento académico. Rev. Prism. Tecnológico 2016, 7, 26-29.

19. Santos Rego, M.Á.; Ferraces Otero, M.J.; Godas Otero, A.; Moledo, L.; del Mar, M. Do cooperative learning and family involvement improve variables linked to academic performance? Psicothema 2018, 30, $212-217$. [CrossRef]

20. Pujolàs, P. El aprendizaje cooperativo como recurso y como contenido. Aula de Innovación Educ. 2008, 170, $37-41$.

21. Muñiz, J.C.I.; García, L.F.G.; y Fernández-Río, J. Aprendizaje Cooperativo; Ediciones Pirámide: Madrid, Spain, 2017.

22. González, S.; Evangelio, C.; Sierra, J.; Fernández, J. Hybridizing pedagogical models: A systematic review. Eur. Phys. Educ. Rev. 2019, 25, 1056-1074. [CrossRef]

23. Bishnoi, N. Collaborative learning: A learning tool advantages and disadvantages. Indian J. Health Wellbeing 2017, 8, 789-791. 
24. Nugraha, F.; Siahaan, P.; Chandra, D.T. The effect of structured individual responsibility on students' achievement increase in cooperative learning science class. J. Phys. Conf. Ser. 2019, 1157, 32-66. [CrossRef]

25. Fisher, B.A. Decision emergence: Phases in group decision-making. Commun. Monogr. 1970, 37, 53-66. [CrossRef]

26. Gil-Madrona, P.; García-Gómez-Heras, S.; Hernández-Barrera, V.; López-de-Andres, A.; López-Gómez, L.; Fernández-García, H.; Carrasco-Garrido, P. University professor behaviors and academic success in childhood education and primary teacher students. Anales de Psicología 2016, 32, 847-854. [CrossRef]

27. Astuti, S.P. Exploring motivational strategies of successful teachers. Teflin J. 2016, 27, 1-22. [CrossRef]

28. Kaendler, C.; Wiedmann, M.; Leuders, T.; Rummel, N.; Spada, H. Monitoring student interaction during collaborative learning: Design and evaluation of a training program for pre-service teachers. Psychol. Learn. Teach. 2016, 15, 44-64. [CrossRef]

29. Durán, D.; Flores, M.; Miquel, E. The Teacher's Role During Cooperative Learning: Should I Leave the Classroom when Students are Independently Working in Teams? J. Classr. Interact. 2019, 54, $24-40$.

30. Page, A. Implementing cooperative learning: A consideration of barriers and enablers. J. Initial Teach. Inq. 2017, 3, 49-52.

31. Deerfield, A. Quantile regression analysis of cooperative learning effects. Int. Rev. Econ. Educ. 2019, 30, 1-17. [CrossRef]

32. Carrasco, C.; Alarcón, R.; y Trianes, M.V. Adaptación y trabajo cooperativo en el alumnado de Educación Primaria desde la percepción del profesorado y la familia. Rev. De Psicodidáctica 2018, 23, 56-62. [CrossRef]

33. Casey, A.; Goodyear, V.A. Can cooperative learning achieve the four learning outcomes of physical education? A review of literature. Quest 2015, 67, 56-72. [CrossRef]

34. Johnson, D.W.; Johnson, R.T. Cooperative Learning in 21st Century. Anales de Psicología 2014, 30, 841-851. [CrossRef]

35. Gillies, R.M. Cooperative Learning: Review of Research and Practice. Aust. J. Teach. Educ. 2016, 41, 39-54. [CrossRef]

36. Slavin, R.E. Cooperative Learning and Academic Achievement: Why Does Groupwork Work? Anales De Psicol./Ann. Psychol. 2014, 30, 785-791. [CrossRef]

37. Gisbert, D.D.; Seuba, M.C.; Coll, M.F. Enhancing expectations of cooperative learning use through initial teacher training. Int. J. Educ. Psychol. 2017, 6, 278-300. [CrossRef]

38. Hsu, C.L.; Chang, Y.F.; Chen, C.H.; Ju, H.F. Collaborative Learning in Teacher Education Community for Pre-service Teacher Practice Learning. In Proceedings of the Asian Conference on Intelligent Information and Database Systems, Da Nang, Vietnam, 14-16 March 2016; Springer: Berlin/Heidelberg, Germany, 2016; pp. 328-335. [CrossRef]

39. Weldeana, H.N.; Abraham, S.T.; Sbhatu, D.B. The effects of small-group cooperative learning strategy on college students' performance of basic mathematics. Ethiop. J. Educ. 2017, 31, 65-93.

40. Hussien, A.M. The Impact of Combining Communicative Traits of Writing with Cooperative Learning on Trainee Teachers' Pedagogical Knowledge and Attitudes. Int. J. Instr. 2020, 13, 813-830. [CrossRef]

41. Tombak, B.; Altun, S. The Effect of Cooperative Learning: University Example. Eurasian J. Educ. Res. 2016, 64, 173-196. [CrossRef]

42. Stevahn, L.; McGuire, M.E. The plot thickens: Supporting pre-service teachers in authentic use of cooperative learning through the Storypath instructional approach. J. Educ. Teach. 2017, 43, 316-327. [CrossRef]

43. Liu, S.H. The perceptions of participation in a mobile collaborative learning among pre-service teachers. J. Educ. Learn. 2016, 5, 87-94. [CrossRef]

44. Cañabate, D.; Nogué, L.; Serra, T.; Colomer, J. Supportive Peer Feedback in Tertiary Education: Analysis of Pre-service Teachers' Perceptions. Educ. Sci. 2019, 9, 280. [CrossRef]

45. Häkkinen, P.; Virtanen, T.; Virtanen, A.; Näykki, P.; Pöysä-Tarhonen, J.; Niilo-Rämä, M.; Järvelä, S. Finnish pre-service teachers' perceptions of their strategic learning skills and collaboration dispositions. J. Educ. Teach. 2019, 46, 71-86. [CrossRef]

46. Ahn, B.; Nelson, M. Assessment of the effects of using the cooperative learning pedagogy in a hybrid mechanics of materials course. Int. J. Mech. Eng. Educ. 2019, 47, 210-226. [CrossRef]

47. Hossain, M. Integration of Structured Cooperative Learning in Mathematics Classrooms. Int. J. Psychol. Educ. Stud. 2018, 5, 23-29. [CrossRef] 
48. Molla, E.; Muche, M. Impact of Cooperative Learning Approaches on Students' Academic Achievement and Laboratory Proficiency in Biology Subject in Selected Rural Schools Ethiopia. Educ. Res. Int. 2018, 2018, 6202484. [CrossRef]

49. Yamarik, S. Does cooperative learning improve student learning outcomes? J. Econ. Educ. 2007, 38, $259-277$. [CrossRef]

50. Vallet-Bellmunt, T.; Rivera-Torres, P.; Vallet-Bellmunt, I.; Vallet-Bellmunt, A. Effectiveness of marketing plan as cooperative learning technique. Eur. Res. Manag. Bus. Econ. 2017, 1-13. Available online: https://www.scipedia.com/public/Vallet-Bellmunt_et_al_2016a\# (accessed on 29 January 2020).

51. Weinberger, Y.; Shonfeld, M. Students' willingness to practice collaborative learning. Teach. Educ. 2018, 1-17. [CrossRef]

52. Morales, J.M.; Olea, B.; Atencia, M.; Madrid, N. Fostering the cooperative learning of mathematics in engineering schools. In Proceedings of the Teaching and Education Conferences (No. 8410856), London, UK, 21-24 May 2019; International Institute of Social and Economic Sciences: London, UK, 2019; pp. 131-133.

53. Hyun, J.; Ediger, R.; Lee, D. Students' Satisfaction on Their Learning Process in Active Learning and Traditional Classrooms. Int. J. Teach. Learn. High. Educ. 2017, 29, 108-118.

54. Uzunboylu, H.; Kinik, E. An evaluation of cooperative learning applications according to teacher opinions. J. Educ. Teach. Train. 2018, 9, 10-23.

55. Zhang, H.; Peng, W.; Sun, L. English cooperative learning mode in a rural junior high school in China. J. Educ. Train. Stud. 2017, 5, 86-96. [CrossRef]

56. Fernandez-Rio, J.; Cecchini, J.A.; Méndez-Giménez, A.; Méndez-Alonso, D.; Prieto, J.A. Design and validation of a questionnaire to assess cooperative learning in educational contexts. Anales De Psicol. 2017, 33, 680-688. [CrossRef]

57. Sun, J.; Anderson, R.C.; Perry, M.; Lin, T.J. Emergent leadership in children's cooperative problem solving groups. Cogn. Instr. 2017, 35, 212-235. [CrossRef]

58. Bentler, P.M. EQS Structural Equations Program Manual; BMDP Statistical Software: Los Angeles, CA, USA, 1989.

59. Hu, L.T.; Bentler, P.M. Cutoff criteria for fit indexes in covariance structure analysis: Conventional criteria versus new alternatives. Struct. Equ. Model. A Multidiscip. J. 1999, 6, 1-55. [CrossRef]

60. Chan, Y.H. Biostatistics 201: Linear regression analysis. Singap. Med. J. 2004, 45, 55-61.

61. Ghani, I.M.M.; Ahmad, S. Stepwise multiple regression method to forecast fish landing. Procedia-Soc. Behav. Sci. 2010, 8, 549-554. [CrossRef] 